\title{
DEGRADATION OF CONVENTIONAL AND OXODEGRADABLE HIGH DENSITY POLYETHYLENE IN TROPICAL AQUEOUS AND OUTDOOR ENVIRONMENTS
}

\author{
Carmen A. ARIAS-VILLAMIZAR* ${ }^{1,2}$ and Alethia VÁZQUEZ-MORILLAS ${ }^{1}$
}

${ }^{1}$ Posgrado en Ciencias e Ingeniería Ambientales, Universidad Autónoma Metropolitana, Unidad Azcapotzalco. Avenida San Pablo 180, Col. Reynosa-Tamaulipas, 02200 Ciudad de México

${ }^{2}$ Universidad del Norte. Km 5 Antigua vía a Puerto Colombia, CP 081007. Barranquilla, Colombia

*Corresponding author: vcarmen@uninorte.edu.co

(Received July 2016; accepted June 2017)

Key words: plastic pollution, micro-plastics, aquatic environments, photo oxidation

\begin{abstract}
Polyethylene is widely used in packaging due to its chemical stability, lightness, impermeability and low cost. However, these properties become questionable when it is discarded. Oxodegradable plastics, which degrade by an abiotic-biotic process, have been promoted as a solution to the pollution caused by plastics. This research assesses the degradability of conventional and oxodegradable high density polyethylene in marine, freshwater, and outdoor tropical environments. Samples of these plastics, with and without previous abiotic degradation, were exposed to direct weathering in the Caribbean Sea and the Magdalena River, in Colombia. Their degradation was evaluated during six months by the formation of carbonyl groups, a decrease in elongation at break and visual evidence of deterioration. We found faster degradation for outdoor, followed by marine and freshwater conditions, evidencing that UV and temperature are the most relevant promoters of degradation, especially for oxodegradable plastics, as evidenced by the increase in carbonyl index. In aqueous environments, all specimens showed the formation of biofilm and in some cases cracks and fragmentation, especially in oxidized oxodegradable high density polyethylene specimens in the marine environment. Even if oxodegradables plastics, and in a lesser degree conventional ones, began their degradation process, they did not achieve complete disintegration or mineralization, due to lack of environmental conditions that can only be guaranteed in carefully monitored waste management systems.
\end{abstract}

Palabras clave: contaminación por plásticos, microplásticos, ambientes acuáticos, fotooxidación

\section{RESUMEN}

El polietileno se utiliza ampliamente en el envasado debido a su estabilidad química, ligereza, impermeabilidad y bajo costo. Sin embargo, estas propiedades son cuestionables cuando se desecha. Los plásticos oxodegradables, que se degradan por un proceso abiótico-biótico, se han promovido como solución. Esta investigación evalúa la capacidad de descomposición del polietileno convencional de alta densidad y el oxodegradable en ambientes tropicales marinos, de agua dulce y a la intemperie. Las 
muestras de polietileno convencional y oxodegradable, con y sin degradación abiótica previa, se expusieron en directo a la intemperie, en el mar Caribe y en el río Magdalena, en Colombia. Se evaluó su degradación durante seis meses por la formación de grupos carbonilo, la disminución del porcentaje de elongación a la ruptura y mediante evidencias visuales de deterioro. Se encontró degradación más rápida para las condiciones al aire libre, lo que demuestra que la radiación UV y el perfil de temperatura son los promotores más pertinentes de la degradación, especialmente en plásticos oxodegradables, como se evidencia por el aumento en el índice de carbonilo. En sistemas acuosos, todas las probetas exhibieron biopelícula, en algunos casos se encontraron grietas y se observó fragmentación. Especialmente se encontró este comportamiento en las probetas de polietileno oxodegradable previamente fotooxidado y expuestas al ambiente marino. Los plásticos con mayor degradación aparente fueron los de polietileno oxodegradable fotooxidado; sin embargo, el material no alcanzó la desintegración completa o mineralización debido a la falta de condiciones propicias, que sólo pueden garantizarse mediante sistemas adecuados de manejo de residuos.

\section{INTRODUCTION}

The increase in the production of polyolefins such as polypropylene, low and high density polyethylene (PP, LDPE, and HDPE, respectively), and their high demand by the current consumer society, is a matter of concern. They are commonly used as packaging materials due to their low cost, mechanical properties, durability, odorless characteristics and low weight (Davis and Song 2006, Ammala et al. 2011). It has been estimated that each year 500 billion to 1 trillion plastic bags are consumed in the world (Roy et al. 2008). However, these materials have also become a problem due to their life cycle, as they are used in short life applications and sometimes are disposed of improperly, polluting aquatic environments (Ryan et al. 2009). This is the case of the Magdalena River, which runs through much of the Colombian territory and is contaminated by plastics (polystyrene, polypropylene, polyethylene and others) discarded by riverside populations, dragging this pollution to the Atlantic Ocean.

The fate and persistence of these polyolefins, whose main polymer chain consists of carbon-carbon bonds, is one of the issues that generate concern in both the scientific community and society. These materials have a high chemical and biological inertness, and therefore their degradation is very complex (Koutny et al. 2006a). Consequently, they have accumulated in marine environments (Barnes et al. 2009, Teuten et al. 2009, Thompson et al. 2009, HidalgoRuz et al. 2012, Wright et al. 2013, Gall and Thompson 2015), lakes (Free et al. 2014, Driedger et al. 2015) and soils (Andrady et al. 1993, Xu et al. 2006, Abrusci et al. 2011). The persistence of polyolefins in the environment is also related to their content of additives, such as antioxidants, flame retardants, and stabilizers, which extend their life (Ammala et al. 2011). Two strategies have been adopted to reduce their presence in the environment. The first one is related to recycling (Al-Salem et al. 2010). The other strategy aims to design materials that after serving its life cycle (Koutny et al. 2006b, Daglen and Tyler 2010), may degrade into assimilable substances in the environment, attending to principles of green chemistry (Lucas et al. 2008, Daglen and Tyler 2010, Abrusci et al. 2011, Ammala et al. 2011).

Degradation of polyolefins is affected by environmental and molecular factors. Environmental parameters include temperature, presence of oxygen and UV radiation, among others. Structural parameters are related to the presence of functional oxidized groups on the polymer chain, which help to promote the reduction of the molar mass, therefore increasing the possibility of a microbial attack (Chandra and Rustgi 1998, Daglen and Tyler 2010). To improve the degradation of polyethylene and retain their properties, new materials - typically referred as oxodegradable - have been designed. They are made from petroleum or natural gas and contain metallic pro-degrading additives which are capable of accelerating the reaction of the polymer with atmospheric molecular oxygen and by incorporating oxygen atoms into the polymer chain (Ammala et al. 2011). In these polymers, the degradation mechanism includes the photo or thermal oxidation (abiotic process) followed by biological degradation. The abiotic phase can be induced by thermal, photolytic, chemical, catalytic and mechanical degradation processes (Singh and Sharma 2008). The second step takes place only if the abiotically degraded plastic faces proper conditions for microbial growth (Kumanayaka et al. 2010) 
Biodeterioration and biodegradation of HDPE, LDPE, PP, and polycarbonate (PC) without additives exposed to sea water have been shown before (Artham et al. 2009). In studies focused on the mechanisms of degradation, it has been found that LDPE can be partially degraded by marine bacteria from pelagic waters (Harshvardhan and Jha 2013). The degradation of HDPE film by two marine fungi without any pre-treatment and pro-oxidant additives has been demonstrated (Devi et al. 2015). Starch blended HDPE in seawater was also studied, and biodeterioration, biodegradation, and change in its physicochemical properties were observed (Muthukumar et al. 2014). Regarding oxodegradable plastics, Chiellini et al. (2007) confirmed that wild microorganism present in river water could act as triggers of degradation. In the study within a marine environment of the degradation of polyethylene carrier bags amended with prodegradant additives ( $\mathrm{d} 2 \mathrm{w}{ }^{\circledR}$ and $\left.\mathrm{EPI}{ }^{\circledR}\right)$, it was found that they presented higher degradation rates than conventional plastics (O'Brine and Thompson 2010), compostable plastic and standard polyethylene in the marine environment. Tensile strength of all materials decreased during exposure, but at different rates. Compostable plastic disappeared from the test rig between 16 and 24 weeks whereas approximately $98 \%$ of the other plastics remained after 40 weeks. Some plastics require UV light to degrade. Transmittance of UV through oxo-biodegradable and standard polyethylene decreased as a consequence of fouling such that these materials received similar to $90 \%$ less UV light after 40 weeks. The data indicate that compostable plastics may degrade relatively quickly compared to oxo-biodegradable and conventional plastics. While degradable polymers offer waste management solutions, there are limitations to their effectiveness in reducing hazards associated with plastic debris. Degradation of LDPE, HDPE, and a blend of LDPE and starch were investigated in controlled laboratory conditions with seawater and microorganism from the sea. It was found that the addition of natural polymers improved weight loss of starch blended materials as compared to conventional ones (Sudhakar et al. 2008). In a study that compared polyethylene with and without pro-degradant, it was concluded that the introduction of pro-degradant improves biodegradability (Muthukumar et al. 2014).

Oxodegradable polyethylene has been promoted in Colombia and other countries as a solution to the environmental problems caused by plastic waste due to failures in waste management practices. It can be expected that some of it will become litter and arrive to aquatic and terrestrial environments. Previous studies have focused either on aquatic or non-aquatic conditions, not allowing to identify if exposure in sea and rivers affects the normal degradation process of these materials. This study aims to assess if the conditions found in aquatic exposure, such as the presence of different ions, lack of UV radiation and formation of biofilm, could hinder or promote the degradation process, when compared to degradation in an outdoor non-aquatic environment. Also, our study allows exploring if the oxodegradable plastic will achieve complete degradation as opposed to the conventional one, and to analyze if a previous oxidation process is required for its degradation. In this context, the present research allows to extend the knowledge of degradation of oxodegradable high density polyethylene in marine and outdoor conditions within an equatorial tropical environment.

\section{MATERIALS AND METHODS}

The degradation of conventional and oxodegradable HDPE in tropical aquatic environments was compared to its degradation in non-aquatic, outdoor conditions.

\section{Raw materials}

Conventional and oxodegradable high density polyethylene (HDPE) commercial bags $(28 \times 35$ $\mathrm{cm}$ and $0.19 \mathrm{~mm}$ thickness) were used to assess degradation. The oxodegradable plastics contained the commercial additive $d 2 \mathrm{w}{ }^{\circledR}$. Probes were cut longitudinally into $10 \times 150 \mathrm{~mm}$ strips. All samples were washed with $70 \%$ ethanol followed by distilled water, dried in a hot air oven for $12 \mathrm{~h}$ at $27^{\circ} \mathrm{C}$ and then brought to room temperature before exposure.

\section{Abiotic treatment (photo-oxidative degradation)}

The purpose of UV weathering was to bring samples quickly to a state that can be compared with natural exposure. To induce degradation, 1080 samples of conventional (C) and oxodegradable (O) HDPE were exposed for $96 \mathrm{~h}$ in an accelerated photo-aging chamber. The temperature was kept at $57 \pm 1{ }^{\circ} \mathrm{C}$ and the wavelength at $340 \mathrm{~nm}$ (ultraviolet radiation UV-A, from eight xenon arc lamps) according to ASTM D5071-06. CO and OO acronyms were used to denote photo-oxidized conventional and oxodegradable HDPE, respectively.

\section{Sampling design}

In this study, we assessed the influence of different environments (marine, river and outdoor), as well as 
the effect of previous oxidation of the tested materials, on the degradation of oxodegradable HDPE. Conventional HDPE was used as a negative control. A floating trap was prepared for each plastic in all the environments and oxidation conditions, adding up to 180 samples of the material. Monthly samplings of 30 specimens of each trap were performed to assess their degradation, during six months. The sampling design is shown in table $\mathbf{I}$.

\section{Exposure of samples}

Three different environments in the equatorial zone of the Colombian Caribbean Sea were used to expose the samples, as shown in figure 1. This area receives direct sunlight throughout the year, producing very stable high temperatures. The locations were selected to allow comparison of the effects of terrestrial conditions, and marine and river water. Polymer samples were placed in floating traps (Fig. 2) for exposure, which were tied to fixed structures for avoiding loss due to the currents. Marine specimens were located in Puerto Velero, in the Colombian Caribbean coast, according to ISO 15314-04. This place is a very touristic area used for the practice of marine sports, with a temperature range of $30-35^{\circ} \mathrm{C}$ and 188-245 h of monthly sunlight. Traps were attached there to pier pilings $\left(10^{\circ} 55^{\prime} 48^{\prime \prime} \mathrm{N}, 75^{\circ} 03^{\prime} 32^{\prime \prime} \mathrm{W}\right)$, at $200 \mathrm{~m}$ from the Puerto Velero beach. In fresh water, they were placed in the same way on the banks of the Magdalena River in Barranquilla $\left(10^{\circ}\right.$ $\left.57^{\prime} 42^{\prime \prime} \mathrm{N}, 74^{\circ} 46^{\prime} 54^{\prime \prime} \mathrm{W}\right)$. This navigable river

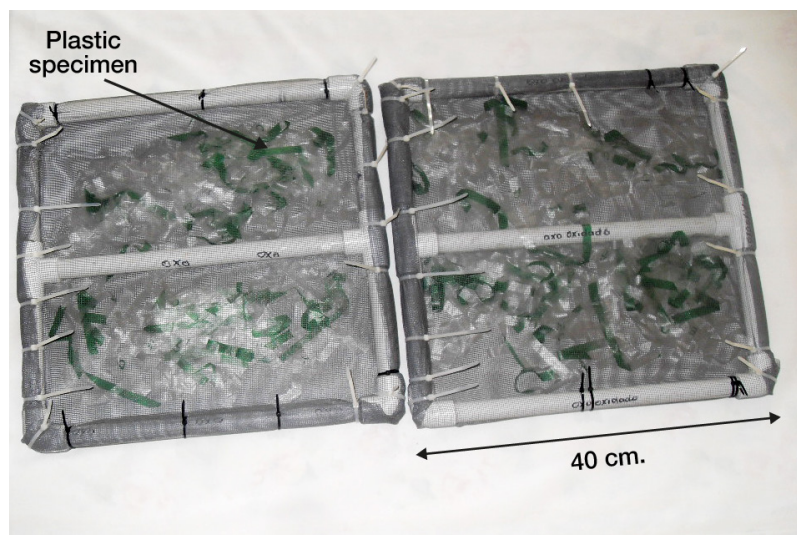

Fig. 2. Floating traps for the exposure of plastics in aquatic and outdoor environments

TABLE I. SAMPLING DESIGN

\begin{tabular}{lllll}
\hline Type of plastic Sea & & \multicolumn{2}{c}{ Number of samples * number of specimens } \\
\cline { 3 - 5 } & & Sea & River & Outdoor \\
\hline Tested material & Oxodegradable HDPE & $6 * 30=180$ & $6 * 30=180$ & $6 * 30=180$ \\
& Previously oxidized oxodegradable HDPE & $6 * 30=180$ & $6 * 30=180$ & $6 * 30=180$ \\
\hline Negative control & Conventional HDPE & $6 * 30=180$ & $6 * 30=180$ & $6 * 30=180$ \\
& Previously oxidized conventional HDPE & $6 * 30=180$ & $6 * 30=180$ & $6 * 30=180$ \\
\hline
\end{tabular}

HDPE $=$ high density polyethylene
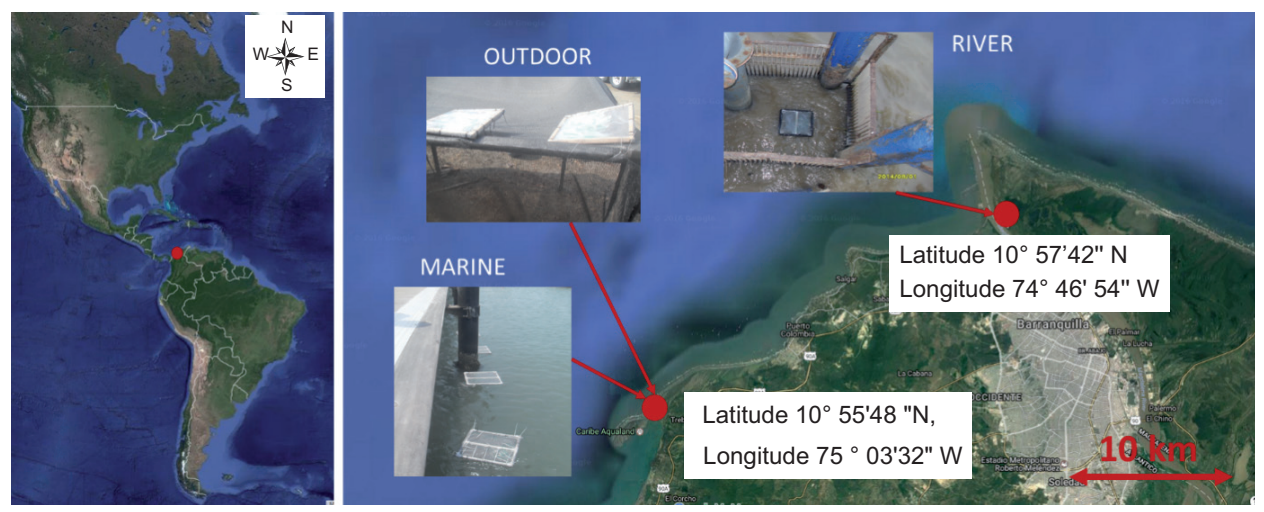

Fig. 1. Exposure locations of samples in Puerto Velero in the Colombian Caribbean coast (marine and outdoor) and in Las Flores in the Magdalena River (freshwater). Source: Google Maps. 
runs along $1500 \mathrm{~km}$ from the south of the country, and many cities and industries have been settled in its borders. Besides residual waters, it carries trash due to the usual practice of throwing wastes directly to streams that lead to the river. The annual temperature in this site was in the range of $26-34{ }^{\circ} \mathrm{C}$; relative humidity was $77-90 \%$, and average sunshine was $213 \mathrm{~h} /$ month. Plastic traps were located in a place called Las Flores, and attached to structures of the Metropolitan Aqueduct of Barranquilla. Outdoor samples were located in a yard in Puerto Velero, tied to a structure built for that purpose. Environmental conditions were the same than for the marine exposure. The samples with and without previous photo-oxidation were exposed 180 days in these environments. Each month thirty probes were retrieved for analysis. During the sampling period, fresh and seawater were characterized. Temperature, dissolved oxygen, conductivity, and $\mathrm{pH}$ were measured using a WTW 340i (Geotech, Denver, CO) pre-calibrated multi-parameter analyzer.

\section{Analytical techniques}

Visual inspection of materials is accepted as evidence of degradation (Shah et al. 2008), thus the first step to evaluate the degradation of materials was a visual recognition to observe roughening, changes in color, fragmentation, and formation of cracks, holes and biofilms, due to thermal and mechanical factors, radiation and the intervention of microorganisms. A Nikon Eclipse E200 microscope with digital camera Sight DS-U3 was utilized to register the changes in photomicrographs.

\section{Mechanical properties}

Parameters such as loss of tensile strength and elongation at break have been used to measure degradation (Andrady et al. 1993). According to ASTM 882-2002, mechanical properties were examined using the LFPlus Universal Testing Machine (Lloyd Instruments, Woonsocket, RI) at room temperature. Deformation rate was $250 \mathrm{~mm}$ per minute, and a 25 $\mathrm{mm}$ gauge length was used.

\section{FTIR spectroscopy}

Chemical changes in the plastic films were measured using Fourier transformed infrared spectroscopy (FTIR) analysis, which was performed using a Nicolet IS10 type thermo spectrophotometer with $2 \mathrm{~cm}^{-1}$ resolution and 32 scans per spectrum (calibrated with polystyrene standards), room temperature of $18{ }^{\circ} \mathrm{C}$ and relative humidity below $60 \%$. The spectral region scanned was from 400 to $4000 \mathrm{~cm}^{-1}$.
A control sample kept at laboratory temperature for the same period was used. Bands due to $\mathrm{CO}$ stretching, $\mathrm{CH}_{2}$ deformation, asymmetrical and symmetrical $\mathrm{CH}_{2}$ bending were studied. The carbonyl group index was determined for taking into account the intensity of the band at $1715 \mathrm{~cm}^{-1}$ relative to the intensity of the band of the methyl group at $1465 \mathrm{~cm}^{-1}$.

\section{Statistical analysis}

The Anderson Darling test and a plotting of residuals were performed to assess the normality of data and to verify normality, homogeneity and aleatority, respectively. One-way analysis of variance (ANOVA) was used to determine whether there are any significant differences between the means of degradation results in the three environments, and also for each plastic (oxidized and non-oxidized) with a $95 \%$ level of confidence. Results are reported as mean \pm SD $(n=30)$ for mechanical properties. Other tests are reported as mean $\pm \mathrm{SD}(\mathrm{n}=3)$. The observed differences were considered statistically significant when $p<0.05$. After ANOVA, Tukey's test was performed to assess differences between materials. The software used was Minitab 15.

\section{RESULTS}

In this section, initial characterization of materials and results regarding their degradation are examined. All traps were recovered with their contents in the three environments. In marine waters, due to the progressive break age of previously oxidized oxodegradable samples (OO), the trap was removed after 150 days, to avoid total loss of the material.

\section{Characterization of raw materials}

In the initial FTIR analysis, conventional and oxodegradable HDPE showed four absorption bands. A weak band appeared at $1715 \mathrm{~cm}^{-1}$ for the oxidized oxodegradable HDPE, evidencing the presence of carbonyl groups formed by artificial weathering. The values of elongation at break, in the initial condition, were $362 \pm 23 \%$ in HDPE and $383 \pm 40 \%$ in oxodegradable HDPE. After $96 \mathrm{~h}$ in the weathering chamber, they decreased to $191 \pm 25 \%$ and $317 \pm$ $37 \%$ for oxodegradable and conventional HDPE, respectively. As expected, oxodegradable HDPE degraded more due to UV radiation.

Table II lists the results for water quality in both environments during the study. The dissolved oxygen and conductivity were significantly different. The lower dissolved oxygen in freshwater is probably 
due to the wastewater that Magdalena River receives from towns located along its banks, and also due to all human activities in its watershed. Consequently, the biochemical oxygen demand is high. The higher conductivity observed in seawater compared with river water is an obvious result, due to the presence of salts.

TABLE II. AVERAGE WATER QUALITY PARAMETERS IN PUERTO VELERO AND LAS FLORES

\begin{tabular}{lcccc}
\hline Parameter & $\begin{array}{c}\text { Marine water } \\
\text { (Puerto Velero) }\end{array}$ & $\begin{array}{c}\text { Freshwater } \\
\text { (Las Flores) }\end{array}$ \\
\hline Temperature $\left({ }^{\circ} \mathrm{C}\right)$ & 27.6 & \pm 0.5 & 28.8 & \pm 0.17 \\
Dissolved oxygen $(\mathrm{mg} / \mathrm{L})$ & 4.05 & \pm 0.49 & 7.07 & \pm 0.27 \\
Conductivity $(\mathrm{mS} / \mathrm{cm})$ & 55.0 & \pm 0.25 & $0.173 \pm 0.01$ \\
$\mathrm{pH}($ Unit de $\mathrm{pH})$ & $8.21 \pm 0.1$ & $7.53 \pm 0.3$ \\
\hline
\end{tabular}

\section{Degradation of plastics}

Deterioration and fragmentation of samples showed clear differences between the three studied places, and occurred mainly for previously oxidized oxodegradable HDPE. In samples exposed to outdoor environments fragmentation of this material occurred after 30 days of exposure, while in marine and freshwater aquatic environments it occurred only after 120 and 180 days, respectively. The fractionation pattern was different in outdoor samples, which presented straight edges, and aqueous systems samples, where rounded edges and biofouling were observed. The non-oxidized oxodegradable plastic started fragmentation in outdoor conditions only after 120 days; no fragmentation was observed for this material in seawater and fresh water after 180 days of exposure. Likewise, non-oxodegradable HDPE specimens (with and without oxidation) in different environments did not show apparent changes.
Oxidized oxodegradable samples clearly showed higher deterioration than the other plastics exposed in the marine environment, presenting a higher frequency of holes and biofilm formation. Besides, the specimens broke easily when handled. This loss of integrity can be attributed to the synergic effect of the previous oxidation and the exposure at sea. Figure 3 shows the fragmentation of photo-aged HDPE in the three environments. Figure 4 shows the biofilm formed in the material after six months of exposure in marine (M), fresh water (R) and outdoor (I) environments. A greater amount of biofilm was found in samples from the sea. Marine organisms, such as seaweed, detritivores, filter feeders, deposit feeder, fungi, and bacteria, rapidly colonized samples exposed in marine water. In samples exposed to freshwater only sediment deposition was observed, while samples exposed outside the water exhibited only dust. As mentioned before, the exposition of oxidized samples (OOM and OOI) was stopped when each material became very fragile, broken and untreatable.

The decrease in the percentage of elongation at break in the samples after 180 days of exposure in seawater (a) and freshwater (b) environments is shown in figure 5. Oxodegradable HDPE in outdoor conditions decreased its elongation at break to $5.41 \%$ in only 60 days, and HDPE to $84.19 \%$ in 180 days (not shown). This results mean that specimens exposed outdoor were degraded more rapidly than those set out in an aqueous medium, thus temperature and solar radiation are the factors that most directly affect these results. Also, as expected, the previously aged material was more susceptible to degradation process, due to oxidation of its structure by UV radiation.

To evaluate if there were significant differences between the three places of exposure, an ANOVA analysis of the elongation at break in different media during 90 days of exposition was performed. Materials exposed outdoor presented significant differences
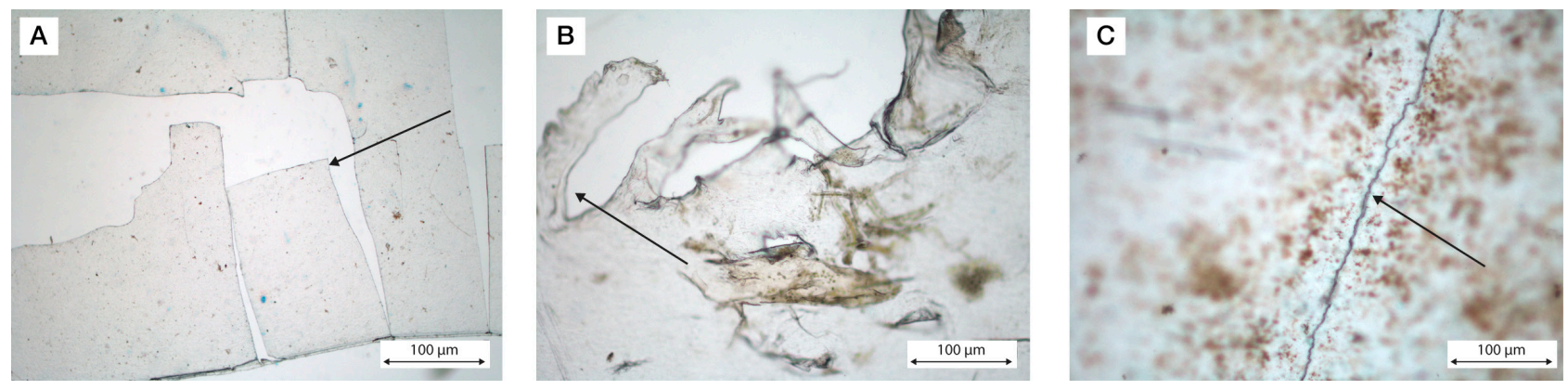

Fig. 3. Microphotographs of previously oxidized oxodegradable high density polyethylene: (A) 30 days in outdoor environment, (B) 90 days in marine environment, and (C) 180 days in freshwater 

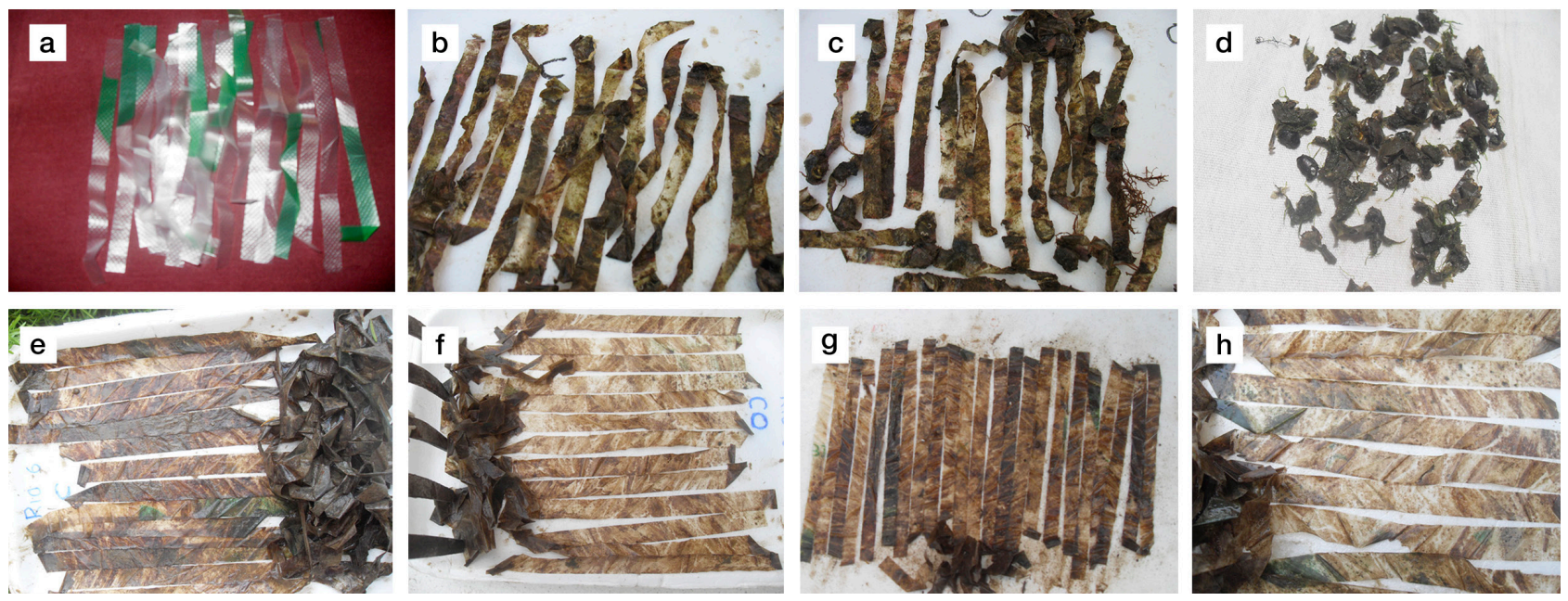

Fig. 4. Biofilm formed after 180 days: (a) Non-exposed high density polyethylene (HDPE) in marine environment, (b) HDPE, (c) oxodegradable HDPE, and (d) oxidized oxodegradable HDPE. In fresh water: (e) HDPE, (f) oxidized HDPE, (g) oxodegradable HDPE, and (h) oxidized oxodegradable HDPE

with respect to materials exposed to fresh water (Fig. 6 and Table III). Regarding differences between materials in each specific place, Tukey test showed

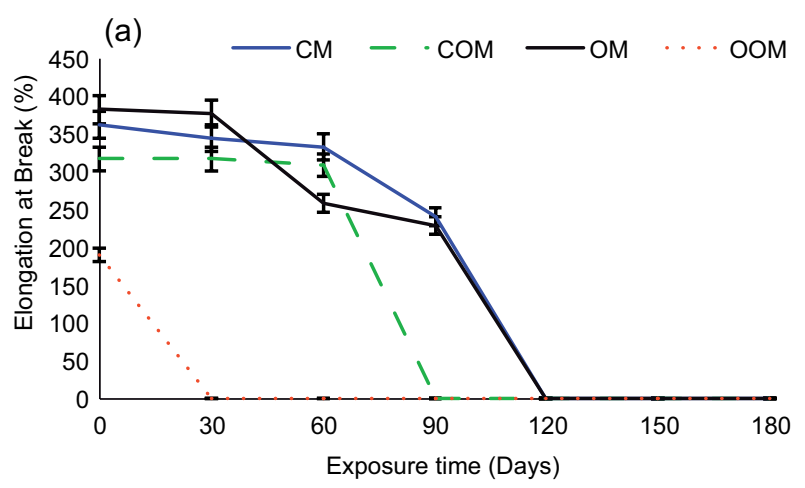

(b)

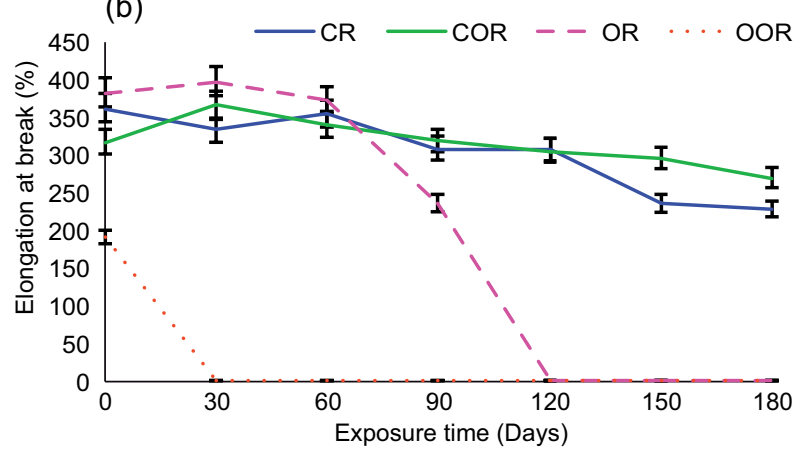

Fig. 5. Comparative percentages of elongation at break in high density polyethylene (HDPE) (C), oxidized HDPE (CO), oxodegradable HDPE (O) and oxidized oxodegradable HDPE (OO), after 180 days (a) marine environment (M), (b) fresh water (R). Error bars represent standard deviation no statistically significant differences for 90 days of observation between CR, COR and OR materials to a confidence level of $95 \%$. In the marine environment, $\mathrm{CM}$ vs. $\mathrm{COM}$ and $\mathrm{OM}$ vs. OOM were not statistically significant at a confidence level of $95 \%$. In the other hand, in outdoor OOI vs. CI and COI materials evidenced statistically significant differences at the $95 \%$ confidence level.

Regarding the analysis of carbonyl indices spectra were identical for conventional and oxodegradable polyethylene at the beginning of the experiment when they were not oxidized. After 180 days, new absorption bands were found, demonstrating oxida-

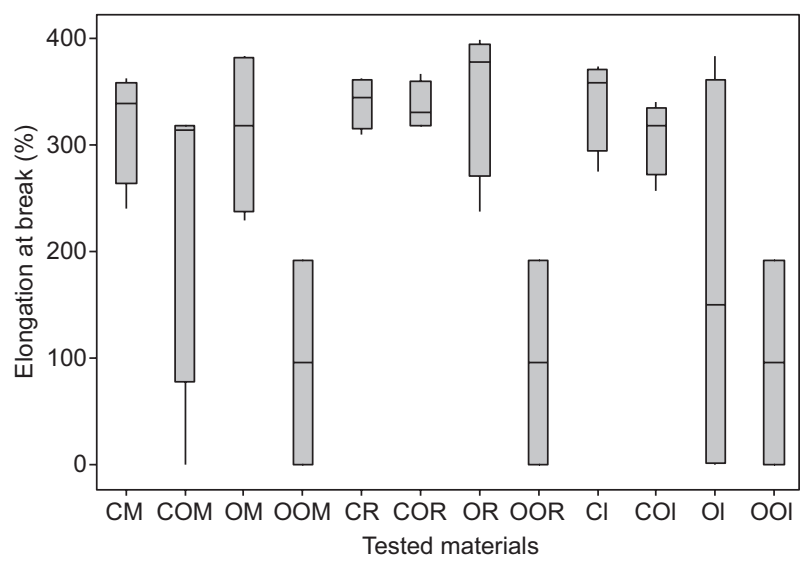

Fig. 6. Comparative percentages of elongation at break in high density polyethylene (HDPE) (C), oxidized HDPE (CO), oxodegradable HDPE $(\mathrm{O})$ and oxidized oxodegradable HDPE (OO), after 90 days in seawater (M), freshwater (R) and outdoor (I) environment. Error bars represent standard deviation 
TABLE III. ANALYSIS OF VARIANCE OF ELONGATION AT BREAK FOR THE DECREASE OF ELONGATION AT BREAK IN SAMPLES LOCATED IN THE THREE DIFFERENT PLACES OF EXPOSURE

\begin{tabular}{lccrc}
\hline Treatment & Month & DF & \multicolumn{1}{c}{ F } & P \\
\hline River & 0 & 3 & 95.79 & 0.000 \\
Marine & 0 & 3 & 95.79 & 0.000 \\
Outdoors & 0 & 3 & 153.93 & 0.000 \\
All & 0 & 11 & 87.80 & 0.000 \\
River & 1 & 2 & 17.26 & 0.000 \\
Marine & 1 & 2 & 2.36 & 0.102 \\
Outdoors & 1 & 1 & 9.35 & 0.004 \\
All & 1 & 7 & 13.07 & 0.000 \\
River & 2 & 2 & 7.45 & 0.000 \\
Marine & 2 & 2 & 2.97 & 0.059 \\
Outdoors & 2 & 1 & 414.60 & 0.000 \\
All & 2 & 7 & 96.37 & 0.000 \\
River & 3 & 2 & 6.11 & 0.005 \\
Marine & 3 & 1 & 0.21 & 0.667 \\
All & 3 & 5 & 6.47 & 0.000 \\
\hline
\end{tabular}

$\mathrm{DG}=$ degrees of freedom, $\mathrm{F}=$ measured value of $\mathrm{F}, \mathrm{P}=\mathrm{p}$-value (significance)

tion processes. The degradation of each material caused the appearance of bands between 1800 and $1600 \mathrm{~cm}^{-1}$, which can be assigned to ketones. This results agrees with those published by other researchs (Chiellini et al. 2006, Huang et al. 2011, Krehula et al. 2014, de la Orden et al. 2015). Figure 7 shows the average results of measurements of the absorbance of the carbonyl index during the experiment. In organic compounds, the band in $1200-1000 \mathrm{~cm}^{-1}$ is characteristic of CO tensions. In the photo-oxidized specimens, an absorption band was recorded around $1714 \mathrm{~cm}^{-1}$ in all samples. In samples exposed to an aqueous medium a weak absorption at 3200 and 3550 $\mathrm{cm}^{-1}$ is indicative of strain -OH.

\section{DISCUSSION}

Our results showed that faster degradation of the studied plastics, especially in those containing pro-oxidants, was achieved outdoors as compared to aquatic environments. Degradation and biodegradation of plastics in the environment are related to the chemical structure of the material and environmental factors (Eubeler et al. 2010). In this research, degradation was influenced by abiotic factors, such as temperature, UV radiation, salinity, turbulence, and previous oxidation of the samples, as well as by formation of biofilm on the surfaces. (a)
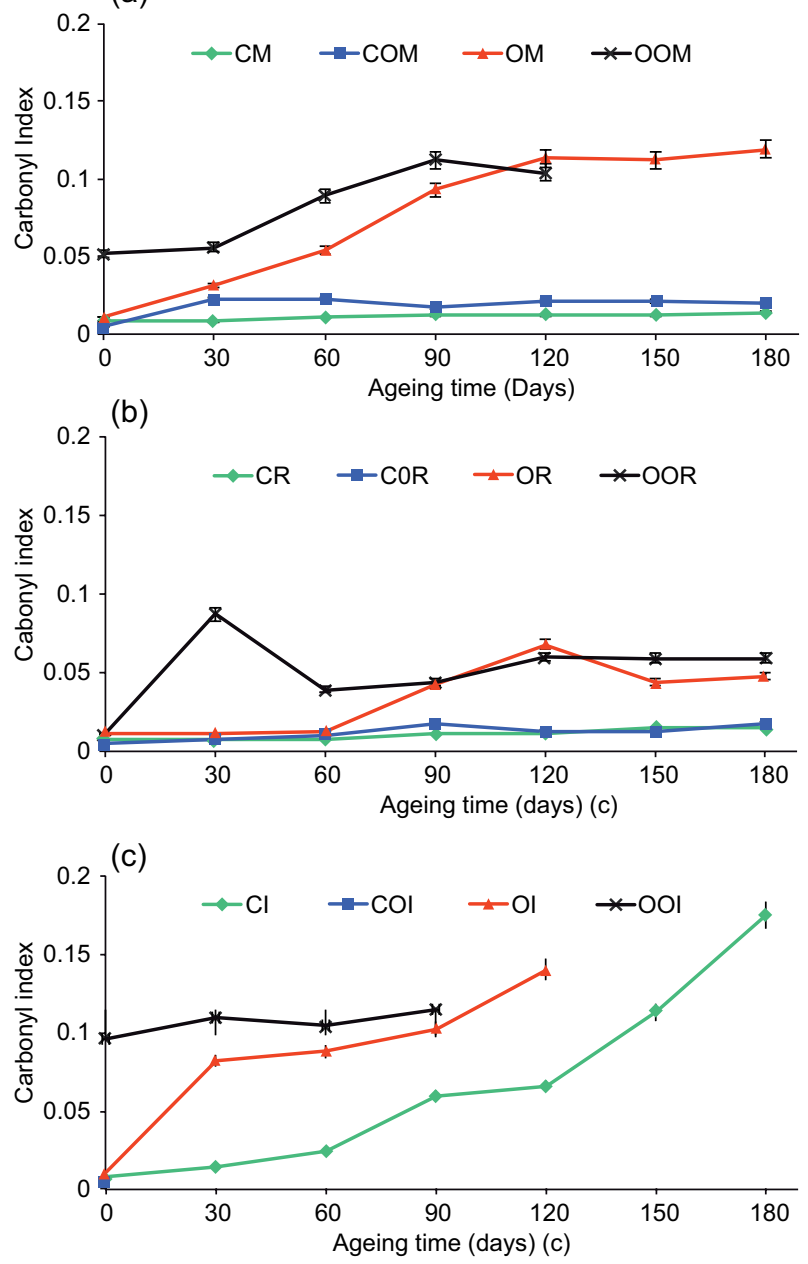

Fig. 7. Carbonyl index in conventional high density polyethylene (HDPE) (C), oxidized HDPE (CO), oxodegradable HDPE (O) and oxidized oxodegradable HDPE (OO), after 180 days of exposure to (a) seawater; (b) freshwater and (c) outdoor. Error bars represent standard deviation

Variation in temperature and higher exposition to UV, due to the absence of biofilm and water, lead to faster degradation of samples exposed outdoors, when compared to those located in the sea or the river. Both factors conduce to changes in morphology and crystallinity (Sen and Raut 2015), and consequently alter macromolecular properties of plastics. While the ambient temperature in the Colombian Caribbean coast can reach $39^{\circ} \mathrm{C}$ during the day and $25^{\circ} \mathrm{C}$ at night, in river and sea values are more stable. Retardation of thermal degradation for plastics, when exposed at sea, has been reported before and attributed to lack of heat build-up in the samples (Pegram and Andrady 1989). In the other hand, photo-degradation promoted by UV lead to free radical formation (Lucas et al. 2008), as shown in the carbonyl index analysis. 
The new functional groups formed lead to degradation in two ways, as promoters of new reactions to accelerate the process and acting as weaker points (compared to the main chain of the polymers) where microorganisms can begin biodegradation if proper conditions are achieved.

In the three environments, degradation began sooner in previously oxidized oxodegradable HDPE than in the conventional plastic, which agrees with previous reports (Koutny et al. 2006b, Fontanella et al. 2010). Previous oxidation is presumed to produce changes at the molecular level (Wiles and Scott 2006), causing breakdown of the polymer chains. However, by the end of the experiment their loss of mechanical properties, changes in chemical structure and appearance was the same than for samples of non-oxidized oxodegradable films.

Although this study was not aimed to evaluate biodegradation by itself, some of the findings showed a first stage indication of microbial intervention in the marine environment. Biofilm formation was higher for plastics exposed in the marine environment, where crustaceans, algae, and other species were observed. Biofouling causes two opposite effects, in one hand the species forming the biofilm can exert mechanical, chemical and enzymatic stress on the specimens, erode the surface and cause depolymerization ( $\mathrm{Gu} 2003$, Shah et al. 2008, Devi et al. 2015) that could lead to mineralization (Lucas et al. 2008, Nowak et al. 2011). In the other hand, biofilm can act as a protective layer against radiation, slowing down the abiotic degradation produced by UV light. In our experiment, biofilm and higher salinity promoted higher degradation in marine water compared to freshwater. In oxidized oxodegradable samples, a large deposit of biofilmaround the cracks of the specimens was observed. Biofilm formation was not observed around cracks in outdoor samples for the same period of exposure. Also, the observed increase and later decrease of carbonyl index in aqueous exposure could be related to the action of microorganisms that consume some of the molecules created (Muthukumar et al. 2014, Devi et al. 2015) or to their dissolution in water.

\section{CONCLUSIONS}

Degradation of plastics has been presented as a partial solution to the environmental problems derived from plastic waste. Oxodegradable plastics have been promoted as a valid answer to the plastic bag issue in some countries like Colombia, due to advantages related to lower increment in cost (compared to other degradable plastics), easiness of handling and processing.

This new plastics could arrive at terrestrial and aquatic ecosystems as a result of wrong management. If this happens, they will degrade faster in terrestrial than in aquatic environments, as a result of higher exposure to temperature and UV radiation, which are considerably high in the studied tropical places. Marine waters promoted higher degradation than freshwater, mainly due to higher salinity and microbial activity, which has been decreased in the river because of its high content of residual water and solid waste. Thus, pollution of water will decrease the possibility of this new plastic to achieve faster and complete degradation.

In this research, oxodegradable plastics with and without previous oxidation showed evidence of faster degradation than conventional HDPE, i.e., the pro-oxidant additives did promote abiotic degradation. However, they did not achieve mineralization or even complete disintegration, as they require specific environmental conditions to trigger and lead their degradation all the way to mineralization. Degradable plastics, in general, should be used for specific applications, collected and treated properly when discarded. If by ignorance, misconceptions about their properties, or negligence they reach the environment, they won't fulfill their purpose.

\section{REFERENCES}

Abrusci C., Pablos J.L., Corrales T., López-Marín J., Marín I. and Catalina F. (2011). Biodegradation of photodegraded mulching films based on polyethylenes and stearates of calcium and iron as pro-oxidant additives. Int. Biodeter. Biodegr. 65 (3), 451-459.

DOI: 10.1016/j.ibiod.2010.10.012

Al-Salem S.M., Lettieri P. and Baeyens J. (2010). The valorization of plastic solid waste (PSW) by primary to quaternary routes: From re-use to energy and chemicals. Prog. Energ. Combust. 36 (1), 103-129.

DOI: 10.1016/j.pecs.2009.09.001

Ammala A., Bateman S., Dean K., Petinakis E., Sangwan P., Wong S., Yuan Q., Yu L., Patrick C. and Leong K.H. (2011). An overview of degradable and biodegradable polyolefins. Prog. Polym. Sci. 36 (8), 1015-1049.

DOI: 10.1016/j.progpolymsci.2010.12.002

Andrady A.L., Pegram J.E. and Tropsha Y. (1993). Changes in carbonyl index and average molecular weight on embrittlement of enhanced-photodegradable polyethylenes. J. Environ. Polym. Degrad. 1 (3), 171179. DOI: $10.1007 / \mathrm{BF} 01458025$ 
Artham T., Sudhakar M., Venkatesan R., Nair C.M., Murty K.V.G.K. and Doble M. (2009). Biofouling and stability of synthetic polymers in sea water. Int. Biodeter. Biodegr. 63 (7), 884-890.

DOI: $10.1016 /$ j.ibiod.2009.03.003

Barnes D.K., Galgani F., Thompson R.C. and Barlaz M. (2009). Accumulation and fragmentation of plastic debris in global environments. Phil. Trans. R. Soc. B 364 (1526), 1985-1998. DOI: 10.1098/rstb.2008.0205

Chandra R.and Rustgi R. (1998). Biodegradable polymers. Prog. Polym. Sci. 23 (7), 1273-1335.

DOI: 10.1016/S0079-6700(97)00039-7

Chiellini E., Corti A., D'antone S. and Baciu R. (2006). Oxo-biodegradable carbon backbone polymers-oxidative degradation of polyethylene under accelerated test conditions. Polym. Degrad. Stab. 91 (11), 2739-2747. DOI: $10.1016 /$ j.polymdegradstab.2006.03.022

Chiellini E., Corti A. and D'Antone S. (2007). Oxo-biodegradable full carbon backbone polymers-biodegradation behaviour of thermally oxidized polyethylene in an aqueous medium. Polym. Degrad. Stab. 92 (7), 137883. DOI: $10.1016 /$ j.polymdegradstab.2007.03.007

Daglen B.C. and Tyler D.R. (2010). Photodegradable plastics: end-of-life design principles. Green Chem. Lett. Rev. 3 (2), 69-82. DOI: 10.1080/17518250903506723

Davis G. and Song J.H. (2006). Biodegradable packaging based on raw materials from crops and their impact on waste management. Ind. Crop. Prod. 23 (2), 147-161. DOI:10.1016/j.indcrop.2005.05.004

de la Orden M.U., Montes J.M., Urreaga J.M., Bento A., Ribeiro M.R., Pérez E. and Cerrada M.L. (2015). Thermo and photo-oxidation of functionalized metallocene high density polyethylene: Effect of hydrophilic groups. Polym. Degrad. Stab. 111, 78-88.

DOI: $10.1016 /$ j.polymdegradstab.2014.10.023

Devi R.S., Kannan V.R., Nivas D., Kannan K., Chandru S. and Antony A.R. (2015). Biodegradation of HDPE by Aspergillus spp. from marine ecosystem of Gulf of Mannar, India. Mar. Pollut. Bull. 96 (1), 32-40.

DOI: 10.1016/j.marpolbul.2015.05.050

Driedger A.G., Dürr H.H., Mitchell K. and Van Cappellen P. (2015). Plastic debris in the Laurentian Great Lakes: A review. J. Gt. Lakes Res. 41 (1), 9-19.

DOI:10.1016/j.jglr.2014.12.020

Eubeler P., Bernhard M. and Knepper T.P. (2010). Environmental biodegradation of synthetic polymers II. Biodegradation of different polymer groups. TrACTrends Anal. Chem. 29 (1), 84-100.

DOI: 10.1016/j.trac.2009.09.005

Fontanella S., Bonhomme S., Koutny M., Husarova L., Brusson J.M., Courdavault J.P., Pitteri S., Samuel G., Pichon G., Lemaire J. and Delort A. (2010). Comparison of the biodegradability of various polyethylene films containing pro-oxidant additives. Polym. Degrad. Stab. 95 (6), 1011-1021.

DOI: 10.1016/j.polymdegradstab.2010.03.009

Free C.M., Jensen O.P., Mason S.A., Eriksen M., Williamson N.J. and Boldgiv B. (2014). High-levels of microplastic pollution in a large, remote, mountain lake. Mar. Pollut. Bull. 85 (1), 156-163.

DOI: $10.1016 /$ j.marpolbul.2014.06.001

Gall S.C. and Thompson R.C. (2015). The impact of debris on marine life. Mar. Pollut. Bull. 92 (1), 170-179.

DOI: 10.1016/j.marpolbul.2014.12.041

Gu J.D. (2003). Microbiological deterioration and degradation of synthetic polymeric materials: Recent research advances. Int. Biodeter. Biodegr. 52 (2), 69-91. DOI: 10.1016/S0964-8305(02)00177-4

Harshvardhan K. and Jha B. (2013). Biodegradation of low-density polyethylene by marine bacteria from pelagic waters, Arabian Sea, India. Mar. Pollut. Bull. 77 (1), 100-106. DOI: 10.1016/j.marpolbul.2013.10.025

Hidalgo-Ruz V., Gutow L., Thompson R.C. and Thiel M. (2012). Microplastics in the marine environment: A review of the methods used for identification and quantification. Environ. Sci. Technol. 46 (6), 30603075 .

DOI: $10.1021 / \mathrm{es} 2031505$

Huang H., Wang Q., Xie B., Yang W. and Yang M. (2011). Thermal oxidation and structural changes of degraded polyethylene in an oxygen atmosphere. J. Macromol. Sci. B 50 (7), 1376-1387.

DOI: $10.1080 / 00222348.2010 .516687$

Lucas N., Bienaime C., Belloy C., Queneudec M., Silvestre F. and Nava-Saucedo J.E. (2008). Polymer biodegradation: Mechanisms and estimation techniques-A review. Chemosphere 73 (4), 429-442.

DOI: 10.1016/j.chemosphere.2008.06.064

Koutny M., Lemaire J. and Delort A.M. (2006a). Biodegradation of polyethylene films with prooxidant additives. Chemosphere 64 (8), 1243-1252.

DOI:10.1016/j.chemosphere.2005.12.060

Koutny M., Sancelme M., Dabin C., Pichon N., Delort A.M. and Lemaire J. (2006b). Acquired biodegradability of polyethylene containing pro-oxidant additives. Polym. Degrad. Stab. 91 (7), 1495-1503. DOI: 10.1016/j.polymdegradstab.2005.10.007

Krehula L., Katančić Z., Siročić A. and Hrnjak-Murgić Z. (2014). Weathering of high-density polyethylene-wood plastic composites. J. Wood Chem. Technol. 34 (1), 39-54. DOI: $10.1080 / 02773813.2013 .827209$

Kumanayaka T.0., Parthasarathy R. and Jollands M. (2010). Accelerating effect of montmorillonite on oxidative degradation of polyethylene nanocomposites. Polym. Degrad. Stab. 95 (4), 672-676. DOI: 10.1016/j.polymdegradstab.2009.11.036 
Muthukumar T., Aravinthana A., Dineshram R., Venkatesan R. and Doble M. (2014). Biodegradation of starch blended high density polyethylene using marine bacteria associated with biofilm formation and its isolation characterization. J. Microb. Biochem. Technol. 6 (3), 116-22. DOI: 10.4172/1948-5948.1000131

Nowak B., Drozd-Bratkowicz M. and Rymarz G. (2011). Microorganisms participating in the biodegradation of modified polyethylene films indifferent soils under laboratory conditions. Int. Biodeter. Biodegrad. 65 (6), 757-767. DOI: 10.1016/j.ibiod.2011.04.007

O’Brine T. and Thompson R.C. (2010). Degradation of plastic carrier bags in the marine environment. Mar. Pollut. Bull. 60 (12), 2279-2283.

DOI: 10.1016/j.marpolbul.2010.08.005

Pegram J.E. and Andrady A.L. (1989). Outdoor weathering of selected polymeric materials under marine exposure conditions. Polym. Degrad. Stab. 26 (4), 333-345. DOI: 10.1016/0141-3910(89)90112-2

Roy P.K., Titus S., Surekha P., Tulsi E., Deshmukh C. and Rajagopal C. (2008). Degradation of abiotically aged LDPE films containing pro-oxidant by bacterial consortium. Polym. Degrad. Stab. 93 (10), 1917-1922. DOI: 10.1016/j.polymdegradstab.2008.07.016

Ryan P.G., Moore C.J., van Franeker J. and Maloney C.L. (2009). Monitoring the abundance of plastic debris in the marine environment. Phil. Trans. R. Soc. B 364 (1526), 1999-2012. DOI: 10.1098/rstb.2008.0207

Sen S.K. and Raut S. (2015). Microbial degradation of low density polyethylene (LDPE): A review. J. Environ. Chem. Eng. 3 (1), 462-473. DOI: $10.1016 /$ j.jece.2015.01.003

Shah A.A., Hasan F., Hameed A. and Ahmed S. (2008). Biological degradation of plastics: A comprehensive review. Biotechnol. Adv. 26 (3), 246-265.

DOI: $10.1016 /$ j.biotechadv.2007.12.005
Singh B. and Sharma N. (2008). Mechanistic implications of plastic degradation. Polym. Degrad. Stab. 561-584. DOI: 10.1016/j.polymdegradstab.2007.11.008

Sudhakar M., Doble M., Murthy P.S. and Venkatesan R. (2008). Marine microbe mediated biodegradation of low-and high-density polyethylenes. Int. Biodeter. Biodegr. 61 (3), 203-213.

DOI: $10.1016 / \mathrm{j}$. ibiod.2007.07.011

Teuten E.L., Saquing J.M., Knappe D.R.U., Barlaz M.A., Jonsson S., Bjorn A., Rowland S.J., Thompson R.C., Galloway T.S., Yamashita R., Ochi D., Watanuki Y., Moore C., Pham H.V, Tana T.S., Prudente M., Boonyatumanond R., Zakaria M.P., Akkhavong K., Ogata Y., Hirai H., Iwasa S., Mizukawa K., Hagino Y., Imamura A., Saha M. and Takada H. (2009). Transport and release of chemicals from plastics to the environment and to wildlife. Phil. Trans. R. Soc. B 364 (1526), 2027-2045.

DOI: $10.1098 /$ rstb.2008.0284

Thompson R.C., Swan S.H., Moor C.J. and von Saal F. (2009). Our plastic age. Phil. Trans. R. Soc. B 364 (1526), 1973-1976. DOI: 10.1098/rstb.2009.0054

Wiles D. and Scott G. (2006). Polyolefins with controlled environmental degradability. Polym. Degrad. Stab, 91 (7) 1581-1592.

DOI: 10.1016/j.polymdegradstab.2005.09.010

Wright S.L., Thompson R.C. and Galloway T.S. (2013). The physical impacts of microplastics on marine organisms: A review. Environ. Pollut. 178, 483-492. DOI: 10.1016/j.envpol.2013.02.031

Xu G., Wang Q., Gu Q., Cao Y., Du X. and Li F. (2006). Contamination characteristics and degradation behavior of low-density polyethylene film residues in typical farmland soils of China. J. Environ. Sci. Health B 41 (2), 189-199.

DOI: $10.1080 / 03601230500365069$ 